\title{
Plant- Species Preference by Birds in Ekiti State University, Ado - Ekiti, Nigeria
}

\section{Ogunyemi 00* \\ Department of Forest Resources and Wildlife Management, Nigeria}

*Corresponding author: Ogunyemi 00, Department of Forest Resources and Wildlife Management, Ekiti State University, Ado-Ekiti, Nigeria, Email: olumideogunyemi80@yahoo. com

\section{Research Article \\ Volume 4 Issue 6}

Received Date: September 21, 2020

Published Date: October 13, 2020

DOI: $10.23880 /$ jenr-16000215

\section{Abstract}

The study was conducted in Ekiti State University, Ado- Ekiti from April to July 2018, with the objectives of identifying plant species preference to foraging birds and to investigate the factors that account for the preference. Sampling areas were stratified based on varying levels of disturbance in the area and transect count techniques was employed to collect data on bird diversity, abundance and distribution while Nested plots were used to collect data on habitat features. A total of 2,381 individual plants were identified belonging to 21 plant species of which five (5) species which include Parkia biglobossa (n=17), Delonix regia $(\mathrm{n}=14)$, Gmelina arborea ( $\mathrm{n}=8)$, Cassia fistula $(\mathrm{n}=7)$ and Eleasi guineesis $(\mathrm{n}=7)$ were highly preferred, Six (6) species were sparsely preferred while only one (1) plant species, Treculia africana $(\mathrm{n}=0)$ were totally avoided by bird species inhabiting the area. The study found variations in bird and vegetation variables assessed for the area. Diversity indices ranged from 2.45 to 0.74 with highest value in location 3 and lowest in location 2 for plant species while species diversity among birds ranged from 2.85 to 2.44 with highest value in location 3 and lowest in location 2 . The findings from this study provide evidence of variable use of different plant species by birds and that certain plant species presence may be an influencing factor on birds' distribution and diversity.

Keywords: Abundance; Distribution; Diversity; Foraging birds; Habitat

\section{Introduction}

Birds are important component of many ecosystems even though their biomass is usually less than that of mammals. They are one of the most conspicuous groups of any fauna. Although they are everywhere, they are certainly more numerous in some places than others. The causes of such variations in most cases are poorly understood. Ekiti State has an extremely interesting and significant avifauna resource. There are at present 166 species of residents birds recorded in the state [1]. Recent survey of avifauna of Ekiti State University varying habitats revealed impressive indices on abundance and wide diversity of birdlife [1]. This variation in composition and diversity has been ascribed to vegetation differences. In recent years many species of birds has become rare and may be threatened. In physical terms, the last two decades have witnessed an accelerated rate of habitat degradation resulting principally from population expansion. A number of studies have examined the possible ways birds use their habitat to permit optimum exploitation and to allow coexistence of different species [2]. Habitat partitioning may occur if, each species possesses a characteristic foraging height distribution [3]. Birds may also divide the vegetation into various horizontal levels [4]. There is evidence that some avian species do have preferences for certain plant species [5]. These factors by acting individually or in concert may interact to produce habitat partitioning for the various avian species in the community and which may invariably influence the abundance and distribution of birds. It has been suggested that plant species diversity 


\section{Journal of Ecology and Natural Resources}

has little effect on community's bird species diversity which instead, is dependent upon foliage height diversity, at least in homogenous environment [6]. It is the vegetation profile which determines bird species diversity and not the plant species present. Morphological and behavioural adaptations for procuring food and differences in prey abundances among tree species may lead to foraging preferences for certain tree species which can in turn dictate the distribution and abundance of birds [7]. Lee and Rotenberry [8] reported that different tree species provide different opportunities for bird foraging, placement of nests, sheltering from the elements and predators, thereby influences different assemblages of birds found in different assemblages of trees. Holmes and Robinson [7] found that rare patchily distributed birds are more selective foragers than common birds and that some selectively rare trees species are strongly preferred by birds. In this study the focus is to specifically investigate the role of floristic by examining the plant species preference of birds in Ekiti State University. The understanding of how birds specifically use vegetation and individual plant species has implications for habitat conservation and management, pointing out important plant species that could be chosen for habitat restoration.

\section{Materials and Methods}

\section{Study Area}

The study was carried out in Ekiti State University campus located on latitude $7.7141 \mathrm{~N}$ and longitude 5.2601 E. Ekiti State University has a total landmass of 2,096 hectares.

The climatic conditions are mainly tropical with two distinct seasons in the year, the wet season (AprilNovember) and a dry season stretching from (November -March). The recorded mean annual rainfall ranges from $1500 \mathrm{~mm}-2000 \mathrm{~mm}$ falling on an average of 270 days per year. The mean minimum temperature is between $210 \mathrm{C}$, while the mean maximum temperature is between is 300C [9]. The vegetation of Ekiti State University campus falls into forest eco-climate vegetation. The principal vegetation comprises of forest trees and shrubs species which co-exist side by side, the herb layer is dominated by grasses. The most frequently occurring grass species are Sporobolus paniculatus, Aristida adscensionis, Pennisetum purpureum and Imperata cylindrical.

\section{Vegetation Survey}

The study areas were stratified and three strata were selected randomly from the landscape of Ekiti State University: Habitable, Pristine and Farmland areas. Abbreviations were used to represent the selected areas; L1 (Habitable area), L2 (farmland area) and L3 (Pristine area). Five sample plots $20 \mathrm{~m} \times 20 \mathrm{~m}$, spaced $50 \mathrm{~m}$ apart were measured and randomly laid within each of the study areas as described by Ogunjemite [10] to estimate tree species composition of the study areas. The vegetation surroundings were examined for the tree species composition, density and frequency occurrence of all trees greater than $30 \mathrm{~cm}$ girth at breast height. Tree species were further divided into 4 classes based on their height: sampling with short trees $(10-15 \mathrm{~m})$, medium trees $(15-23 \mathrm{~m})$, tall trees $(>23 \mathrm{~m})$ and dead trees. The identification of tree species was obtained through the knowledge of local botanists (using vernacular species names and features such as colour of the tree bark and leaves). For plant species that were difficult to identify in the field, taxa were coded according to the respective study sites, pressed and brought to qualified plant taxonomist at the Herbarium of Ekiti State University for identification to the species level following the comparison method with herbarium specimens and using the published volumes of Flora of West Africa. Consequently, the tree species present in the three areas were sampled and the proportion of availability within the study sites was determined.

\section{Avifauna Survey}

The census method was used to survey the abundance and diversity of avifauna species in each of the study areas of Ekiti State University. The survey was conducted on monthly basis from April to July, 2018 in the three stratified study areas (Habitable, Pristine Forest and Farmland areas) of Ekiti State University, using the point count survey as described by Bibby [11]. The relative value of each habitat for attracting different bird species was determined by thoroughly searched of each plot for birds and search effort was uniformly distributed throughout each plot to minimize counting bias. The birds were observed in each of the stratified areas for four consecutive days every month. To avoid effects of pseudo-replication in the counting of birds, transect were reasonably space out by $300 \mathrm{~m}$ distance apart [12]. Bird's species and their foraging activities were observed in each area. Individual trees were searched thoroughly for 5 minutes to detect bird species activities on tree species on which bird was recorded. Data collection was carried out from 0700-1000 and 1600-1800 hours to coincide with time the activities of birds were prominent [13]. In all counting points, records were made of bird species and the trees species on which the birds forage through direct observation. The birds were observed with the aid of binoculars (Olympus 10 and 42) to the species level and their taxonomic groups were properly categorized based on field guide to birds of Western Africa [14].

\section{Data Analysis}

At each study plot, the species and individuals bird 
and tree species were counted. The abundance of plant and bird species was determined as the number of individual species per study sites. Floristic and avifauna diversity were determined using the following: species richness, diversity indices, evenness (E) and Shannon-Wienner diversity index $\left(\mathrm{H}^{\prime}\right)$ which was used to compare the diversity in species composition of the three areas. The floristic and bird species similarity between the three areas was calculated using Sorenson index which compares the species composition. The relative abundance of plant and bird species within each area (equitability or evenness) was calculated as $\mathrm{E}=\mathrm{H}^{\prime} / \mathrm{LnS}$ Magurran [15], where $\mathrm{S}$ is the number of species and $\mathrm{H}^{\prime}$ the Shannon-Wiener index of diversity. The quantification of tree-species selectivity for birds was determined through preference index calculated as $E=\left(p^{i}-r^{i}\right)\left(p^{i}+r^{i}\right)$ Ivelv [16] where $\mathrm{p}^{\mathrm{i}}$ is the proportions of the tree species used by a particular bird species, $r^{i}$ is the proportion of tree species composition occupied by the tree species in the study area.

\section{Results}

\section{Vegetation Composition of the Study Areas of Ekiti State University}

A total of 20 tree species were recorded across the three stratified areas during the study. The identified 20 species belong to 12 families and with regards to the distribution of these species, habitable area possesses 15 plant species belonging to 9 families while the pristine and farmland areas contributed 18 species distributed in 11 families and 13 species belonging to 8 families respectively. At the habitable area Fabaceae and Verbaceae families had the highest number of plant species, comprising $30 \%$ of tree species recorded respectively. At the pristine area, the plant families with the highest number of plant species dominance were Fabaceae and Verbaceae with $25 \%$ of the recorded plant species. At the farmland area where 8 plant families were recorded, the contribution of the Verbaceae and Arecaceae families is pronounced with 4 Tree species comprising of
$20 \%$ of the total trees species recorded. The least number of families (8) was recorded at the farmland area while the largest numbers of families (11) were recorded at the pristine stratified area of the university. Eight (8) families and 12 tree species were common to habitable and pristine area. However, 8 families and 12 tree species were found uniquely in common between pristine and farmland areas, 7 families and 11 tree species were found common to the habitable and farmland areas while 11 families were common to the three stratified areas of study (Table 2). The variable woody plant species diversity had the highest index value of 2.90 in the pristine area followed by that of the habitable area with 2.69, while the farmland area recorded the least value 2.37. The density of trees in the study areas varies from one location to another. The individual trees were more prevalent in the farmland area of the study as vividly shown from the density value (Table 1). A total of 2,381 individual trees belonging to 20 plant species were recorded within fifteen (15) $20 \mathrm{~m}$ $\times 20 \mathrm{~m}$ sample plots laid within the area.

The test conducted to assess vegetation variables in the three study areas shows significant differences in habitat characteristics among the study areas. In the farmland area of the study the total tree density was 0.77 trees per meter square while that of other two study areas habitable and pristine areas were 0.26 and 0.16 trees per meter square respectively (Table 1 ). In the three study areas, Tectona grandis $(\mathrm{n}=295)$, Eleasi guineensis $(\mathrm{n}=1342)$ and Gliricidia sepium ( $n=190$ ) had the highest frequency of occurrence. The percentage similarities among the study areas with respect to plant species were subjected to the Sorenson's percentage similarity index analysis. The index result showed that the similarity of plant species was found higher between the pristine and farmland areas than between the habitable and other two areas. The result of the comparison indicated that $15.4 \%$ of plant species between the pristine and farmland areas were found similar. However, the least similarity $(9.5 \%)$ is recorded between the habitable and pristine areas (Table 3).

\begin{tabular}{|c|c|c|c|}
\hline Attributes & L1 & L2 & L3 \\
\hline Woody plant species & 15 & 13 & 18 \\
\hline Tree density & 0.26 & 0.77 & 0.16 \\
\hline No of individual plant species & 523 & 1512 & 346 \\
\hline Tall trees > 23m & 5 & 7 & 10 \\
\hline Medium trees (15-23m) & 8 & 2 & 4 \\
\hline Short trees (10-15m) & 2 & 12 & 3 \\
\hline Dead tree stands & 10 & 15 \\
\hline
\end{tabular}

Table 1: Attributes of Vegetation in the three Study Areas of Ekiti State University 


\begin{tabular}{|c|c|c|c|c|c|}
\hline S NO & Trees species & Family & L1 & L2 & L3 \\
\hline 1 & Delonix regia & Fabaceae & 20 & - & 3 \\
\hline 2 & Pakia biglobosa & Mimosoideae & 26 & 34 & 42 \\
\hline 3 & Gmelina arborea & Verbaceae & 60 & 20 & 33 \\
\hline 4 & Mangifera indica & Meliaceae & 30 & 41 & 45 \\
\hline 5 & Baphia nitida & Papilionoideae & - & - & 9 \\
\hline 6 & Cassia fistula & Fabaceae & 1 & - & - \\
\hline 7 & Plumeria alba & Apocynacaea & 11 & 10 & 12 \\
\hline 8 & Eucalyptus globules & Myrtacaea & 15 & - & - \\
\hline 9 & Treculia Africana & Moraceae & - & 5 & 2 \\
\hline 10 & Eleasi guineensi & Arecaceae & 5 & 1287 & 50 \\
\hline 11 & Vitex doniana & Verbaceae & 1 & - & 10 \\
\hline 12 & Tectona grandis & Verbaceae & 250 & 30 & 15 \\
\hline 13 & Gliricidia sepium & Fabaceae & 70 & 50 & 70 \\
\hline 14 & Spathodea nilotica & Bignoniaceae & - & - & 5 \\
\hline 15 & Ficus religiosa & Moraceae & - & 1 & - \\
\hline 16 & Ficus benjamina & Moraceae & - & - & 3 \\
\hline 17 & Croton zambesicus & Euphorbiacea & 15 & 3 & 5 \\
\hline 18 & Roystonea regia & Arecaceae & 10 & 4 & 8 \\
\hline 19 & Spondias mombin & Anacardiacea & - & - & 10 \\
\hline 20 & Anacardium occidentalis & Anacardiacea & 9 & 15 & 9 \\
\hline 21 & Dead tree stand & - & 10 & 12 & 15 \\
\hline
\end{tabular}

Table 2: Species Composition, Family and Abundance of Trees in the Study Areas of Ekiti State University.

\begin{tabular}{|c|c|}
\hline Comparisons between areas & Percentage (\%) \\
\hline L1\&L2 & 9.5 \\
\hline L1 \&L3 & 9.6 \\
\hline L2\&L3 & 15.4 \\
\hline
\end{tabular}

Table 3: Sorenson's Percentage of Similarity Index for Plant Species in the study area

The highest tree species diversity and richness occurred in the pristine area with values 2.45 and 2.91 respectively. Habitable area ranked next to the pristine area in tree species diversity (1.83) while habitable area had the next higher value of species richness (2.24). The highest species evenness index was registered in the pristine area (0.65). This is followed by that of habitable area (0.42) while the farmland had the least evenness index value (0.16). Simpson's index ranked highest in the pristine area with value (0.89), indicating that out of 100 pairs of different tree species at random, 89 were composed of different species (Table 4).

\begin{tabular}{|c|c|c|c|c|c|c|}
\hline Species & \multicolumn{3}{|c|}{ Birds } & \multicolumn{3}{|c|}{ Plants } \\
\hline Location & \multirow{3}{*}{ L 1} & \multirow{3}{*}{ L 2} & \multirow{3}{*}{ L 3} & \multirow{3}{*}{ L1 } & \multirow{3}{*}{$\mathrm{L} 2$} & \multirow{3}{*}{ L3 } \\
\hline Diversity & & & & & & \\
\hline Indices & & & & & & \\
\hline No. of species & 15 & 13 & 18 & 19 & 18 & 25 \\
\hline Individuals & 523 & 1512 & 346 & 127 & 157 & 191 \\
\hline Shannon-Wienner index & \multirow{2}{*}{1.83} & \multirow{2}{*}{0.74} & \multirow{2}{*}{2.45} & \multirow{2}{*}{2.46} & \multirow{2}{*}{2.44} & \multirow{2}{*}{2.85} \\
\hline$\left(\mathrm{H}^{\prime}\right)$ & & & & & & \\
\hline Species richness & 2.24 & 1.64 & 2.91 & 3.72 & 3.56 & 4.57 \\
\hline Evenness & 0.42 & 0.16 & 0.65 & 0.62 & 0.6 & 0.69 \\
\hline Simpson index 1- D & 0.74 & 0.27 & 0.89 & 0.87 & 0.88 & 0.92 \\
\hline
\end{tabular}

Table 4: Tree Diversity, Evenness and Diversity Indexes 


\section{Avifauna Species Composition of the Study Areas of Ekiti State University}

A diverse population of birds has been identified in the study areas of Ekiti State University. A total of 38 bird species belonging to 29 families were observed in the three study areas of the university (Table 5).

\begin{tabular}{|c|c|c|}
\hline Family & Species & Common names \\
\hline Pycnontidae & Pycnontus barbatus & Common bulbul \\
\hline Passeridae & Passer griseus & Northern grey-headed sparrow \\
\hline Musophagidae & Crinifer piscator & Western great plantain eater \\
\hline Estrildidae & Lochura bicolor & Black and white manikin \\
\hline Nectariniidae & Cinnyris venustus & Variable sun bird \\
\hline Bucerotidae & Tockus fasciatus & African pied hornbill \\
\hline Columbidae & Streptopelia senegalensis & Laughing dove \\
\hline Nectariniidae & Cinnyris coccinigastrus & Splendid sunbird \\
\hline Nectariniidae & Cinnyris cupreus & Copper sunbird \\
\hline Viduidae & Vidua macroura & Pin-tailed whydah \\
\hline Nectariniidae & Anthreptes collaris & Collared sunbird \\
\hline Ploceidae & Ploceus cucullatus & Village weaver \\
\hline Cisticolidae & Camaroptera brevicaudata & Grey-backed carmaroptera \\
\hline Estrildidae & lonchura culcullata & Bronze manikin \\
\hline Falconidae & Falco tinnunculus & Common kestrel \\
\hline Motacillidae & Motacilla aguimp & African pied wagtail \\
\hline Cuculiformes & Chrysococcyx caprius & Didric cuckoo \\
\hline Musophagidae & Anthus leucophrys & Plain backed pipit \\
\hline Phasianidae & Pternistis bicalcaratus & Double-spurred francolin \\
\hline Columbidae & Streptopelia semitorquata & Red eyed dove \\
\hline Accipitridae & Elanus axillaris & Black shouldered kite \\
\hline Cuculidae & Centropus senegalensis & Senegal coucal \\
\hline Recurvirostridae & Recurvirostra avosetta & Pied avocet \\
\hline Alcedinidae & Corythornis cristatus & Malachite king fisher \\
\hline Accipitridae & Kaupifalco monogrammius & Lizard buzzard \\
\hline Monarchidae & Terpsiphone rufivente & Red bellied paradise flycatcher \\
\hline Nectariniidae & Cinnyris choropygius & Olive bellied sunbird \\
\hline Columbidae & Turtur afer & Blue spotted wood dove \\
\hline Picidae & Mesopicos xantholophus & Grey wood pecker \\
\hline Nectariniidae & Chalcomitra adelberti & Buff throated sunbird \\
\hline Pycnontidae & Thescelocichla leucopleura & Swamp palm bulbul \\
\hline Sylviidae & Sylvietta virens & Green crombec \\
\hline Musophagidae & Crinifer zonurus & Eastern grey plantain eater \\
\hline Apodidae & Apus apus & Common swift \\
\hline Accipitridae & Polyboroides typus & African harrier-hawk \\
\hline Sturnidae & Onychognathus fulgidus & Chestnut-winged starling \\
\hline Oriolidae & Oriolus nigripennis & Black-winged oriole \\
\hline Cuculidae & Chrysococcyx caprius & Didric cuckoo \\
\hline
\end{tabular}

Table 5: Bird species observed on 21 plant species in the study areas of Ekiti State University.

It was noted that Nectarinidae family (33\%) followed by Columbidae (33\%), Pycnontidae (33\%) were the most dominant families among the study areas. The family Nectarinidae emerged as the most dominant family with 6 
species. Out of 38 bird species recorded in the study area, 8 bird species were found exclusively inhabiting the habitable area, 15 species were exclusive to the farmland area and no bird species was exclusively attached to the farmland area of study. The most dominant exclusive bird species among the study areas were Doubled spurred francolin (Pternistis bicalcaratus) and Pied avocet (Recurviro stravosetta) respectively. The pristine area had more complex bird community structure in terms of higher species richness, diversity and evenness (Table 6).

\section{Tree species preferences of birds during the study}

Thirty-eight (38) bird species were observed in the three study areas during 80 observation hours distributed over 16 days. $26 \%, 20 \%, 12 \%, 0.6 \%$ was predominantly granivores, insectivores, frugivores, nectarivores, herbivores, omnivores and carnivores respectively (Figure 2). The birds' community analysis showed a division of three ecological species groups i.e.-.

- A group of 20 birds' species with a habitat preference for habitable area.

- A group of 23 bird species with a habitat preference for farmland area.

- A group of 23 bird species with a habitat preference for pristine area.

The most frequently observed bird species in habitable areawere splendid sunbird (Cinnyriscoccinigastrus), Common bulbul (Pycnontus barbatus), Northern grey headed sparrow (Passer griseus), Laughing dove (Streptoplia senegalensis). In farmland, doubled spurred francolin (Pternistis bicalcaratus), Common bulbul (Pycnontus barbatus), African pied hornbill (Tockus fasciatus), Bronze manikin and Red eyed dove. In pristine area, Pied avocet (Recurvirostra avosetta), Common bulbul (Pycnontus barbatus), Bronze manikin (Lonchura culcullata) and Common swift (Apus apus). The bird species distribution in the study areas of Ekiti State University showed that 5, 6 and 12 bird species were exclusive in their distribution to the habitable, farmland and pristine areas of the university respectively, 9 birds' species shared two habitats while 8 birds' species were common to the three habitats. The tree preference index for bird species was compared between the study areas and the outcome showed variation in the preference index (Table 6). In Habitable area (L1) Cassia fistula, Parkia biglobosa, Mangifera indica and Vitex doniana had the highest preference index, in Farmland area (L2) Eleasi guineensis, Ficus religiosa, Roystonea regia and dead tree stands ranked highest while in Pristine area (L3) Eleasi guineensis, Spondias mombim, Gliricidia sepium, Cassia fistula and dead tree stands had the highest preference index values. (Table 6 \& Figure 1)

\begin{tabular}{|c|c|c|c|}
\hline Species & L 1 & L 2 & L 3 \\
\hline Denonix regia & 0.0162 & - & - \\
\hline Treculia Africana & 0.002 & - & - \\
\hline Pakia biglobosa & 0.051 & - & - \\
\hline Gmelina arborea & 0.003 & - & - \\
\hline Magnifera indica & 0.033 & 0.002 & -01 \\
\hline Cassia fistula & 0.165 & - & - \\
\hline Eucalyptus globulus & 0.018 & - & 0.069 \\
\hline Plumeria alba & 0.002 & - & - \\
\hline Eleasiguineensi & 0.018 & 0.2 & - \\
\hline Vitex doniana & 0.033 & - & - \\
\hline Tectona grandis & 0.0007 & - & - \\
\hline Gliricidia sepium & - & 0.022 & 0.003 \\
\hline Roystonea regia & - & 0.037 & - \\
\hline Ficus religiosa & - & 0.202 & 0.01 \\
\hline Ficus Benjamin & - & - & 0.003 \\
\hline Croton zambesicus & 0 & 0.002 & 0.003 \\
\hline Spondias mombin & - & - & 0.003 \\
\hline Anacardium occidentale & - & - & 0.133 \\
\hline Baphia nitida & - & - & - \\
\hline Spathodea nilotica & - & 0.199 & \\
\hline
\end{tabular}

Table 6: Preference index (PI) for bird species observed on tree species in Ekiti State University. 


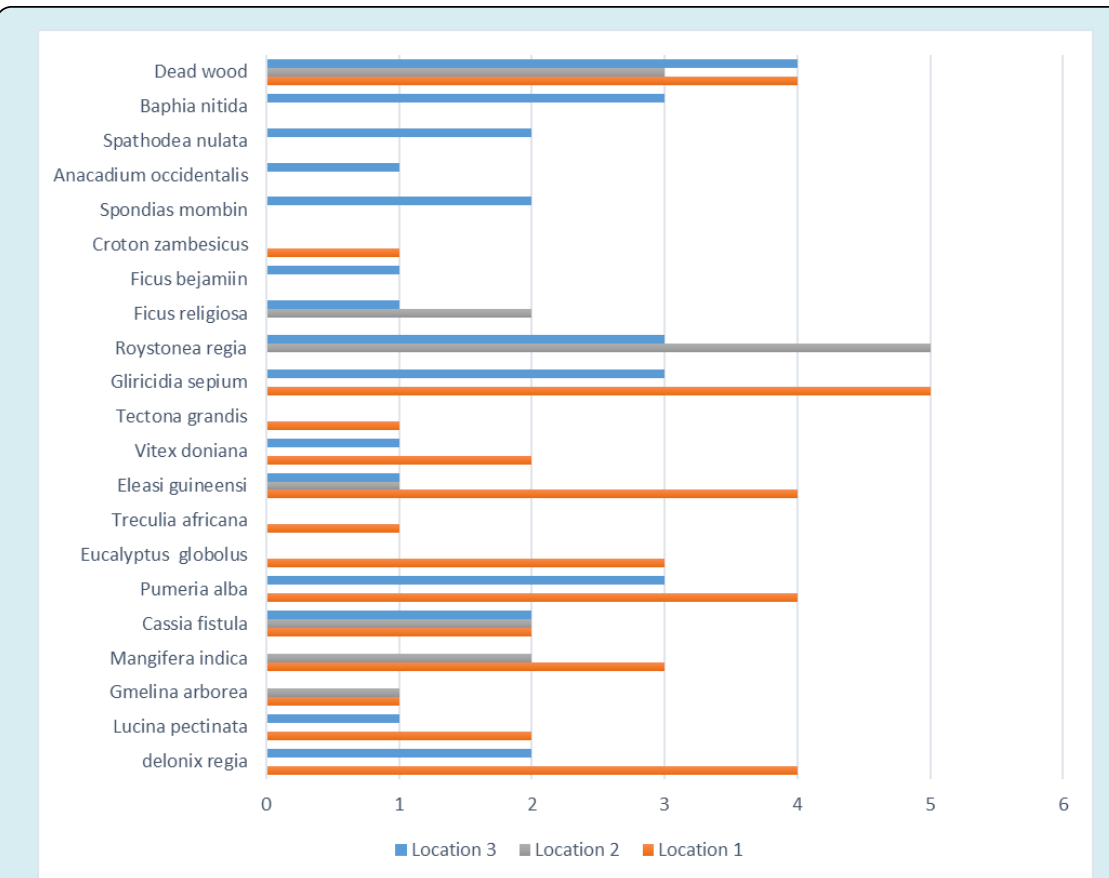

Figure 1: Tree species utilization by birds in Ekiti State University.

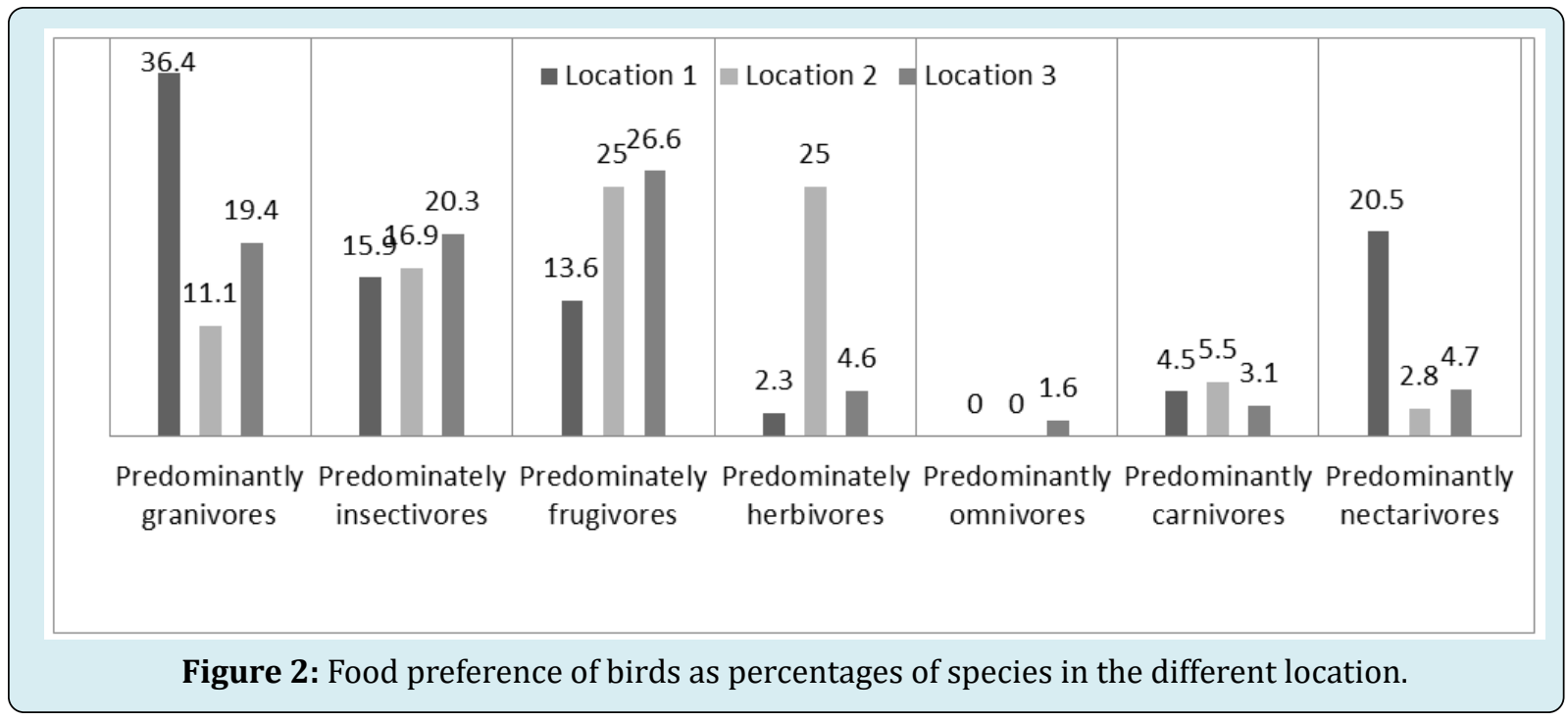

\section{Discussion}

The tree species composition of a habitat can be an important component of habitat selection by bird species [17]. The perceived importance of vegetation structure on the distribution and abundance of birds Holmes and Robinson [7] has long over shadowed the effects of floristic composition of avian community structure. In Ekiti State University, the plant species preference of birds in the three stratified areas has revealed that the bird species inhabiting the university vegetation types are diverse and showed preference for diverse plant species that constitute the vegetation of the area. The study vividly revealed that certain tree species were clearly preferred by the 21 bird species observed in the area, whereas others were avoided or use in proportion to availability. This agrees with the findings of Gabbe [17] in the Cache river flood plain, that birds had strong preferences for a diverse set of tree species and that all foraging bird species were selective of tree species. The 21 bird species observed during the study showed variation in the selection of tree species and frequency at which each tree species is being foraged on. It is evident that bird species in the area have 


\section{Journal of Ecology and Natural Resources}

strong preference for 7 plant species Delonix regia, Plumeria alba, Gliricidia sepium, Eleasis guineensis, Roystonea regia, Baphia nitida and dead tree stands. The field observation indicates that birds forage much more frequently on the seven (7) plant species than on its important value (IV). In the habitable and pristine areas of the university, seven (7) plant species out of 20 species found in the areas were of strong preference to bird species, while in the farmland area, only one (1) plant species and dead woods were preferred to tree species found in the area which is consistent with results obtained by Warburton [18] that the native bird species monitored in forest ecosystem of North Okari made variable use of plant species present in the study area. The low number of plant species strongly preferred in farmland area may be linked with the low tree density in area. Similar results were found by Aaron [19] that Warbler bird species was relatively uncommon in the Cache study area, probably because of past selective logging of bald cypress and the rarity of sycamore trees. Tree species in study areas were unequally utilized within and between studies areas by birds, the study further showed that strength of birds' preferences varies among tree species within each areas of study. 7 plants species (Delonix regia, Plumeria alba, Gliricidia sepium, Eleasi guineensis, dead wood) were recorded were strongly preferred, 2 plant species (Mangifera indica, Eucalyptus globules) were present in the habitable area of the study were fairly preferred 12 plant species had low bird species preference. In the study area, 5, 2 and 5 plant species were highly preferred in the habitable, farmland and pristine areas respectively. Also only 2 plant species fairly preferred by birds were found in the farmland 7, 5 and 11 plant species had low preferment in the habitable, farmland and pristine areas while the- trees species that were totally avoided 7,14 and 6 in the habitable, farmland and pristine areas respectively. The preference index (PI) for birds' species observed in tree species of the study areas shows that tree species such as Lucina leucociphola, Mangifera indica, Vitex doniana, Eucalyptus globules, Eleasi guineensi, Cassia fistula and Delonix regia had high preference index values in the habitable area. In the farmland area of the study, tree species Ficus religiosa, Roystonea regia and dead wood has high preference index while in pristine area, dead wood Eleasis guineensis, Gliricidia sepium, Spondias mombin and Cassia fistula ranked high in preference index. Gabbe [17] was of the opinion that preference for certain features of habitat structure can confound tree species preference. Kathleen [20] had observed that the variation in bird species selectivity among tree species may be due to food abundance, availability and quality. He further stressed on the importance of foliage to birds in protecting them from predators and in severe weather conditions as well as provision of shelters in the nest sites of numerous species. Most bird species observed during the study were predominantly granivores, insectivores, frugivores and herbivores including common bulbul, Double spurred francolin, Common kestrel, Bronze manikin, Pied avocet. Plants therefore are extremely important to these birds not only as foraging substrates but also as direct sources of food. This finding is similar to what was found by Blake and Loiselle [21], those frugivores dominates numerically in the lowland wet forests in Costa rica. Holmes and Robinson [7] also reported that variable use of different tree species and height tiers by birds can be ascribed to their morphological characteristics, abundance and accessibility of the preferred prey, food and the degree of interspecific competition [18]. The present study revealed that insects of various species were observed on varying heights of plants species preferred by the observed birds especially the dead woods, thus this may be in part responsible for insectivorous birds' preferences for tree species in the area. The presence of mature fruiting trees of high diameter at breast height (DBH) and of high fruit production indicates why frugivorous birds preferentially use the area. The study has established variable use of vertical stratification different plant species by birds inhabiting the three stratified study in areas of Ekiti State University. It was observed that plant species play important roles in birds' distribution and diversity by providing majorly shelter and food for the birds residing and breeding in the area.

\section{Conclusion}

The university vegetation has high ornithology value in view of the presence of diverse bird species and therefore deserves more conservation attention. This study provides information on plant species preference of birds in Ekiti State University. The outcome of the study revealed that bird species inhabiting the ecosystems of Ekiti State University are not only selective in the utilization of plant species but shows marked variation in their rate of usage of the selected plants in the area. The birds in the stratified areas of the university shows variations in the diversity and abundance which may be partly due to the difference in the floristic of the study areas associated with the roles played by individual plant species in the provision of shelter and food for the birds residing and breeding in the area. The higher proportion of birds utilizing the seven plant species is consistent with the hypothesis, which holds that the carrying capacity of birds in a habitat is a function of food, cover availability, micro-climate variation and predation pressure. Birds are valuable indicators of environmental qualities and as a vital component of ecosystems; birds are important seeds dispersers, pollinators and predators of insects. Therefore, it is very important to develop an effective management scheme to maintain the ecological qualities by not overlooking plant species preference of birds in habitat restoration projects. 


\section{Journal of Ecology and Natural Resources}

\section{References}

1. Ogunyemi OO (2012) Ecological Diversity and Abundance of Birds in the Wetlands of Ekiti, Nigeria. Unpublished Ph.D. Thesis Federal University of Technology, Akure, pp: 231.

2. Chalfoun AO, Schmidt KA (2012) Adaptive BreedingHabitat Selection: Is it for the birds? The Auk 129(4): 589-599.

3. Miguel AM, Roberto BC (1993) Habitat and Foraging Substrate use of three Basileuterus Warblers from Central Brazil. Ornitologia Neotropical 4(2): 69-76.

4. Rutten G, Erisslin A, Hemp A, Fischer M (2015) Vertical and Horizontal Vegetation Structure across Natural and Modified Habitat Types at Mount Kilimanjaro. PLoS ONE 10(9): e0138822.

5. Duan, Q., Goodale, E and Quan, R. (2014) Bird fruit preferences match the frequency of fruit colours in Tropical Asia. Scientific Reports 4: 5627.

6. Tews J, Brose U, Grimm V, Tielborger K, et al. (2003) Animal species diversity driven by habitat heterogeneity / diversity: the importance of keystone structures. J Biogeography 31(1): 79-92.

7. Holmes RT, Robinson SK (1981) Tree species Preferences of Foraging Insectivores birds in Northern hardwoods forest. Oecologia 48: 31-35.

8. Lee PY, Rotenberry JT (2005) Relationships between bird species and tree species assemblages in forested abitats of eastern North America. Journal Biogeography 32(7): 1139-1150.

9. Mengistu DA, Salami AT (2007) Application of remote sensing and GIS in land use and Land cover mapping and change detection in a part of South Western Nigeria. African Journal Environmental Sciences Technology 1(5): 99-109.

10. Ogunjemmite (2007) Habitat structure of Chimpanzee community in Nigeria: A comparison of site. Acta Zoological Sinical 53(4): 579-588.
11. Bibby CJ, Burgess ND, Hill DA, Mustoe SH (2000) Bird Census, Technique. Academic Press London.

12. Oksanen L (2001) Logic of experiments in ecology: Is pseudo- replication a pseudo-issue? Oikos 94(1): 27-38.

13. Jones M (1998) Study design. In: Bibby C, Jones M, Marseden S (Eds.), Expendition Field Techniques, Bird surveys. Royal Geographical society with the Institute of British Geographer, London, pp: 15-34.

14. Borrow N, Demey R (2004) Birds of Western Africa, published by Christopher Heim an imprint of A and C Black (publishers) LTD., 37 Soho square, London WSD 3QZ.

15. Magurran AE (2004) Measuring Biological Diversity Blackwell Publishing.

16. Ivlev BC (1955) Gyorui no eiyouseitaigaku. Sinn- KagakuBunnkenn- Kankoukai, Yonago translated from Russian into Japanese in 1965.

17. Gabbe AP, Robinson SK, Brawn JD (2001) Tree - Species of Foraging Insectivorous Birds: Implications for Floodplain Forest Restoration. Conservation Biology 16(2): 462-470.

18. Warburton B, Kingsford SJ, Lewitt DM, Spurr EB (1992) Plant Species Preferences of birds in Lowland Rimu (Dacrydium cupressinum) Forest- Implications for selective-logging. New Zealand Journal Ecology 16(2): 119-126.

19. Aaron PG, Scott KR, Jeffrey DB (2002) Tree- Species Preferences of Foraging Insectivorous Birds: Implications for Floodplain Forest Restoration. Conservation Biology 16(2): 462-470.

20. Kathleen EF (1978) Tree species used by birds in logged and unlogged mixed- coniferous forests. Wilson Bulletin 90(2): 221-238.

21. Blake JK, Loiselle DA (1992) Fruits in the Diets of Neotropical Migrant Birds in Costa Rica. Biotropica 24(2): 200-210. 